\title{
A Study About Attitude Of Parents Towards Participation Of Females In Sports
}

\author{
Shaista Naz \\ Department of Education \\ Sindh Madressatul Islam University \\ Hina Fazil \\ Department of Special Education \\ University of Punjab \\ Nasir Sulman \\ Department of Special Education \\ University of Karachi
}

\begin{abstract}
The history of sports is generally one of the masculine domination. That's why women in sports have been a topic completely ignored by most scholars in Pakistan. The paramount purpose of this study was to find out the attitude of parents which are having influence on the female participation in sports so that a realistic standard programme for their increased participation in sports is assured. The findings of the study suggested that the parental attitude was having a significant influence in moving female participation in sports.

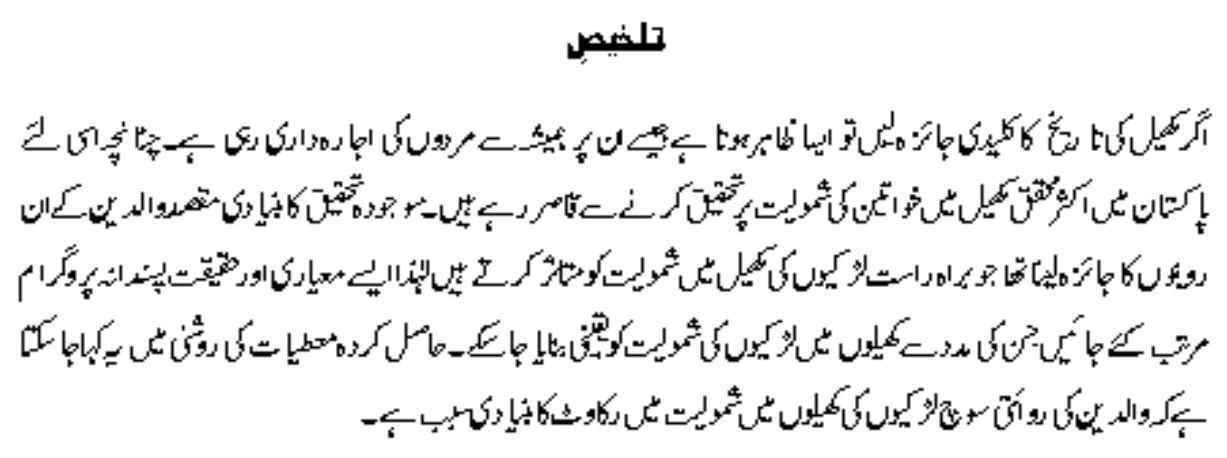

Key Words: Attitude, Sports, Participation, Girl Child, Parents

\section{Introduction}

Historically sports has been a myth rather than a reality for women because in society she has to assume roles in private spheres like wife, mother, house maker and there by immensely contributing expressive enrichment of social life. Parents allow boys a greater freedom to explore their play environment and that they believe female child is more 
fragile and in need of assistance (Dennison, 2002). It is believed that parental behaviour is natural that they stem from a deeply embedded cultural ideology which unconsciously assumes that females are unable or incapable of performing certain activities without help (Huddleston, Mertesdorf \& Araki, 2002). This belief dictates parental behavior and triggers a sequence of parent-infant handling which indirectly dissuades females from most forms of physical activities. Females in response to parental influence learn to view physical activities as behaviour reserved especially for males.

Bourntiler \& Giovanni (1983) were of the opinion that because girls play indoor more and have limited experiences in interacting with their environmental surrounding they tend not to play team or competitive game. Udoh (1988) reported that "In general, a father will show his son how to hold a ball and as the son grew older, how to throw and catch. Daughters may learn appropriate female activities because her mother serves as a role model."

In our society, sport, vigorous play/work, and risk taking are still considered appropriate for males and are still negatively coded for females. This concept is supported by parents, other adults, teachers, coaches, text books and media. The basic problem is the public perception of sports as an activity which is a sexual signature of masculinity the media seems to support and perpetuate this attitude.

The participation of female athletes may be related with the gender of the coach they were engaged. The decline in number of women, coaching females may also contribute to the participation percentage of females in organized sports.

Acosta \& Carpenter (1990) have attempted to explain the decline in the number of women, coaching females. They attributed this decline to the media's reinforcement of stereotypical ideology of women in sports has contributed to the dearth of female sport leaders.

There are some major areas of concern with regard to co-educational physical education during adolescence and these appear to be underlying causes which differently and detrimentally affect the behaviour of girls in mixed groups. On the one hand there are biologically based concerns of the onset of secondary sexual characteristics (menstruation) and sex differences in physical capacities; on the other hand there are the socially-based concerns of intensified gender-related role expectations and different teacher expectations.

Following puberty, biological differences between girls and boys emerge which favour males in all categories of physical activity. Most girls are at a disadvantage at that time in activities when compared with boys while participating in physical education activities. 
According to Shelby (1977) physical contact and sexuality related issues have the potential to increase in co-educational physical education classes. Teacher-student and student-student contact, sickness and the required provision of treatment of injuries, short skirts can become problem areas in mixed sex groupings. Browne, Embrey \& Rate (1987) observed that girls are harassed both verbally and physically by individual boys and groups of boys. Girls are verbally abuse by boys, so girls withdraw from sports. They further explained that boys ridicule girls about their body shape leading to embarrassment for girls.

Scraton (1990) provided an interesting finding that "In team games, forced integration means that only the most proficient girls have a chance to play, leaving the majority of girls unable to participate because either they are not skilful enough, or the boys exclude them."

Pakistan is a society where sports are integral to the formation of dominant forms of masculinity. Through playing sports adolescent boys recognize them as being masculine. Whilst for young women, participation in sports on one hand challenges hegemonic notions of ideal feminist, while at same time challenging sports as a male domain. Taylor \& Toohey (1998) found that girls often refrained from participation due to factors including time constraints, family responsibilities, lack of social skills, lack of information and culturally appropriate programs. They further added that the use of public space has also an impact on the female physical activity patterns.

Finally, because of the traditional, cultural and social attitudes towards women in sports, some women have been limited in their opportunities and their outlook. Many girls have not reached the full potential because they have been defeated psychologically even before they compete. Female participation in sports has been hampered by myths and superstitions.

To consider all these facts in mind, the present study was conducted to ascertain female students studied in under graduate programs of selected universities of Karachi, on the influence of parental involvement on their participation in sports. This is with the bid to unveil the status of family as a necessary factor in female participation in sports.

\section{Methodology}

The study was conducted in the city of Karachi which has a large number of educational institutions including universities supported by the Federal Government of Pakistan and the provincial governments. There are also various private universities supported by philanthropists, businessmen, welfare bodies and societies. Ten universities which are included in the approved list of Higher Education Commission, Pakistan was selected 
through lottery method of random sampling. Table 1 summarizes the universities surveyed, along with their response rate, accordingly.

Table 1

The Distribution of the Participants According to the University

\begin{tabular}{|c|c|c|c|c|}
\hline Name of the University & Sector & $\begin{array}{c}\text { Survey } \\
\text { Distribute }\end{array}$ & $\begin{array}{c}\text { Survey } \\
\text { Received }\end{array}$ & $\begin{array}{l}\text { Response } \\
\text { Rate }\end{array}$ \\
\hline 1. University of Karachi & Public & 250 & 232 & $93 \%$ \\
\hline 2. Dow University of Health Sciences & Public & 100 & 91 & $91 \%$ \\
\hline $\begin{array}{l}\text { 3. The Federal Urdu University of Arts, } \\
\text { Sciences and Technology }\end{array}$ & Public & 100 & 67 & $67 \%$ \\
\hline 4. Jinnah University for Women & Private & 90 & 78 & $87 \%$ \\
\hline $\begin{array}{l}\text { 5. NED (NadirshawEduljeeDinshaw) } \\
\text { University of Engineering and } \\
\text { Technology }\end{array}$ & Public & 60 & 43 & $72 \%$ \\
\hline $\begin{array}{l}\text { 6. The Institute of Business Management } \\
\text { (IoBM) }\end{array}$ & Private & 40 & 23 & $58 \%$ \\
\hline $\begin{array}{l}\text { 7. ShaheedZulfikar Ali Bhutto Institute of } \\
\text { Science and Technology (SZABIST) }\end{array}$ & Private & 40 & 28 & $70 \%$ \\
\hline $\begin{array}{l}\text { 8. Sir Syed University of Engineering and } \\
\text { Technology, ( SSUET) }\end{array}$ & Private & 40 & 37 & $93 \%$ \\
\hline $\begin{array}{l}\text { 9. Preston Institute of Management Sciences } \\
\text { and Technology (PIMSAT) }\end{array}$ & Private & 40 & 26 & $65 \%$ \\
\hline 10. Hamdard University (HU) & Private & 40 & 29 & $73 \%$ \\
\hline Total & & 800 & 654 & $82 \%$ \\
\hline
\end{tabular}

Total 654 (82\% response rate) female students who were pursuing their under graduate course during the academic year $2012-2013$ were finally participated in the study. These participants were those who have either participated or not participated in any sports activity.

\section{Instrument}

The questionnaire was prepared taking into consideration the multifarious aspects of the study. The questionnaire contained three major sections. Section one was intended to get personal information related to the name, age and department of the respondent. This section was also asked about parental occupation, educational qualification and their monthly income. Information regarding nativity and availability of playing facilities during early years were also gathered. Section two contained 35 statements intended to get information regarding their parents' attitude towards female participation in sports 
during early years and afterwards. The last section of the questionnaire contained the participants' suggestions for more female participation in sports.

A three point scale was used to find out to what extent the statements describe the parental influence on female participation in sports. The response for every statement were made on a three point scale such as agreed, undecided and disagreed. Scoring was done as follows:

- A score of ' 3 ' was assigned to 'Agree'

- A score of '2' was assigned to 'Undecided'

- A score of ' 1 ' was assigned to 'Disagree'

The questionnaire was developed at various stages. In the first stage, the investigators personally interviewed various university female students those who have either participated or not participated in sports and also met various experts in physical education. The selection of the statements was done keeping in the mind that they should be specific, clear, simple, related to the study and double negatives were eliminated. The prepared questionnaire was evaluated by the experts in the fields of psychology, physical education and women studies. They were asked critically to evaluate the statements of the questionnaire about their appropriate and give suggestions for improvement.

In the light of the recommendations from the experts, necessary changes were made in the questionnaire and it was finalized. The questionnaire was further tried out as a pilot study on fifteen under graduate female students to judge whether they understand the statements and were able to give responses and it was found out to be quite suitable.

\section{Findings}

The results of the analysis are presented below. The response on parental influence on female participation was analyzed and presented in Table- 2 .

Table 2

Response on Parental Factors Influence on Female Participation in Sports

\begin{tabular}{|c|c|c|c|c|}
\hline Statements & Agree & Undecided & Disagree & $\begin{array}{c}\text { Chi } \\
\text { Square }\end{array}$ \\
\hline $\begin{array}{l}\text { 1. My parents are actively interested in } \\
\text { sports. }\end{array}$ & $104(16 \%)$ & $249(38 \%)$ & $301(46 \%)$ & 91.870 \\
\hline $\begin{array}{l}\text { 2. They use to take me out with them to } \\
\text { watch sports competitions. }\end{array}$ & $144(22 \%)$ & $72(11 \%)$ & $438(67 \%)$ & 313.570 \\
\hline $\begin{array}{l}\text { 3. They provided me with sporting } \\
\text { equipment in my sport of interest. }\end{array}$ & $91(14 \%)$ & $105(16 \%)$ & $458(70 \%)$ & 363.370 \\
\hline 4. They allowed me watch sports on TV. & $562(86 \%)$ & $0(0 \%)$ & $92(14 \%)$ & 753.690 \\
\hline $\begin{array}{l}\text { 5. My parents encouraged me to participate } \\
\text { in sports in spite of my academic work } \\
\text { load. }\end{array}$ & $177(27 \%)$ & $78(12 \%)$ & $399(61 \%)$ & 231.930 \\
\hline
\end{tabular}




\begin{tabular}{|c|c|c|c|c|c|}
\hline & $\begin{array}{l}\text { My parents encouraged me to participate } \\
\text { in sports though I have to perform certain } \\
\text { domestic activities after university hours. }\end{array}$ & $58(9 \%)$ & $144(22)$ & $452(69 \%)$ & 365.130 \\
\hline & $\begin{array}{l}\text { My parents were always cooperative and } \\
\text { understanding though I come late to house } \\
\text { after participating in students' activities. }\end{array}$ & $20(3 \%)$ & $150(23 \%)$ & $484(74 \%)$ & 468.000 \\
\hline & $\begin{array}{l}\text { My parents never feared that my } \\
\text { participation in sports may lead to losing } \\
\text { their personal vigilance over my } \\
\text { behaviour. }\end{array}$ & $13(2 \%)$ & $432(66 \%)$ & $209(32 \%)$ & 359.710 \\
\hline & $\begin{array}{l}\text { My parents never felt that their dignity in } \\
\text { the society would be degraded because of } \\
\text { my participation in sports. }\end{array}$ & $255(39 \%)$ & $59(9 \%)$ & $340(52 \%)$ & 172.830 \\
\hline 10. & $\begin{array}{l}\text { My parents always encouraged me to wear } \\
\text { sports uniform though many parents } \\
\text { considered it as immodest. }\end{array}$ & $12(1 \%)$ & $14(2 \%)$ & $628(96 \%)$ & 1066.170 \\
\hline & $\begin{array}{l}\text { Community always recognizes outstanding } \\
\text { sports women for their achievement. }\end{array}$ & $464(71 \%)$ & $39(6 \%)$ & $151(23 \%)$ & 415.890 \\
\hline 12. & $\begin{array}{l}\text { Coverage of women sports by electronic } \\
\text { media created lot of enthusiasm among } \\
\text { women. }\end{array}$ & $6(1 \%)$ & $517(79 \%)$ & $131(20 \%)$ & 587.370 \\
\hline 13. & $\begin{array}{l}\text { My friends \& relative always encouraged } \\
\text { my participation in sports. }\end{array}$ & $72(11 \%)$ & $26(4 \%)$ & $556(85 \%)$ & 714.720 \\
\hline & $\begin{array}{l}\text { Participation in sports will help to get a } \\
\text { good name in the society. }\end{array}$ & $562(86 \%)$ & $0(0 \%)$ & $92(14 \%)$ & 753.690 \\
\hline 15. & $\begin{array}{l}\text { My parents feel that attitude of the men in } \\
\text { the society will discourage women to take } \\
\text { parts in sports. }\end{array}$ & $582(89 \%)$ & $0(0 \%)$ & $72(11 \%)$ & 856.960 \\
\hline 16. & $\begin{array}{l}\text { Religious beliefs \& family customs never } \\
\text { restricted my participation in sports. }\end{array}$ & $569(87 \%)$ & $0(0 \%)$ & $85(13 \%)$ & 784.000 \\
\hline & $\begin{array}{l}\text { Social customs \& } \begin{array}{c}\text { conventions } \\
\text { opposed my participation in sports. }\end{array} \\
\text { oper }\end{array}$ & $497(76 \%)$ & $0(0 \%)$ & $157(24 \%)$ & 543.360 \\
\hline & $\begin{array}{l}\text { I continued to participate in sport even } \\
\text { after adolescence. }\end{array}$ & $33(5 \%)$ & $0(0 \%)$ & $621(95 \%)$ & 1039.840 \\
\hline & $\begin{array}{l}\text { My parents allowed me to train by men } \\
\text { coach. }\end{array}$ & $33(5 \%)$ & $0(0 \%)$ & $621(95 \%)$ & 1034.410 \\
\hline 20. & $\begin{array}{l}\text { I always feel that participation in sports has } \\
\text { got no link with my marriage prospects. }\end{array}$ & $392(60 \%)$ & $0(0 \%)$ & $262(40 \%)$ & 332.490 \\
\hline 21. & $\begin{array}{l}\text { Men always prefer to select sports women } \\
\text { as their brides. }\end{array}$ & $27(4 \%)$ & $6(1 \%)$ & $621(95 \%)$ & 1038.370 \\
\hline & $\begin{array}{l}\text { Now a day women doesn't have any } \\
\text { restriction to participate in sports because } \\
\text { of the nativity urban or rural. }\end{array}$ & $117(18 \%)$ & $20(3 \%)$ & $517(79 \%)$ & 586.990 \\
\hline 23. & $\begin{array}{l}\text { Play field is a great leveler where no } \\
\text { difference of colour, creed, religion, \& } \\
\text { status is shown. }\end{array}$ & $6(1 \%)$ & $6(1 \%)$ & $642(98 \%)$ & 1117.470 \\
\hline 24. & $\begin{array}{l}\text { Growth \& development of the human beings } \\
\text { can be maximized through participation in } \\
\text { sports. }\end{array}$ & $144(22 \%)$ & $72(11 \%)$ & $438(67 \%)$ & 319.630 \\
\hline
\end{tabular}




\begin{tabular}{|c|c|c|c|c|}
\hline $\begin{array}{l}\text { 25. Participation in sports will develop the } \\
\text { quality of punctuality \& discipline. }\end{array}$ & $7(1 \%)$ & $0(0 \%)$ & $647(99 \%)$ & 1158.490 \\
\hline $\begin{array}{l}\text { 26. Women always possess the physical } \\
\text { stamina required for sports activities. }\end{array}$ & $0(0 \%)$ & $549(84 \%)$ & $105(16 \%)$ & 719.310 \\
\hline $\begin{array}{l}\text { 27. Women have the mental courage to accept } \\
\text { failures in competitive field of sports. }\end{array}$ & $0(0 \%)$ & $576(88 \%)$ & $78(12 \%)$ & 815.290 \\
\hline $\begin{array}{l}\text { 28. Women are equally tough to men \& also } \\
\text { fit to participate in highly competitive } \\
\text { sports. }\end{array}$ & $471(72 \%)$ & $6(1 \%)$ & $177(27 \%)$ & 454.930 \\
\hline $\begin{array}{l}\text { 29. Participation in sports help women to } \\
\text { develop the ability to get along with team } \\
\text { mates as well as the people around. }\end{array}$ & $12(2 \%)$ & $465(71 \%)$ & $177(27 \%)$ & 423.310 \\
\hline $\begin{array}{l}\text { 30. Participation in sports activities provides } \\
\text { relaxation from monotonous life. }\end{array}$ & $7(1 \%)$ & $0(0 \%)$ & $647(99 \%)$ & 1158.490 \\
\hline $\begin{array}{l}\text { 31. Participation in sports will remove tension } \\
\text { \& worries. }\end{array}$ & $7(1 \%)$ & $0(0 \%)$ & $647(99 \%)$ & 1158.490 \\
\hline $\begin{array}{l}\text { 32. The quality of boldness to face any kind of } \\
\text { difficult task is developed through } \\
\text { participation in sports. }\end{array}$ & $7(1 \%)$ & $0(0 \%)$ & $647(99 \%)$ & 1158.490 \\
\hline $\begin{array}{l}\text { 33. I prefer participating in group games rather } \\
\text { than individual games. }\end{array}$ & $412(63 \%)$ & $0(0 \%)$ & $242(37 \%)$ & 362.410 \\
\hline $\begin{array}{l}\text { 34. I get adequate \& proper information } \\
\text { regarding sports competitions for women. }\end{array}$ & $7(1 \%)$ & $0(0 \%)$ & $647(99 \%)$ & 1158.490 \\
\hline $\begin{array}{l}\text { 35. Sports will make women lose their } \\
\text { faminity. }\end{array}$ & $386(59 \%)$ & $78(12 \%)$ & $190(29 \%)$ & 202.122 \\
\hline
\end{tabular}

The table shows response to questions on parental influence on female participation in sports. Responses to the statement taken for discussion are reported below:

1. There is a lack of sports awareness among the parents.

2. Parents did not take their daughters out to watch sports events and competitions.

3. Parents did not provide sports' equipment to their girl child in their sport of interest.

4. Parents allowed their daughters to watch sports channel.

5. Parents felt that their daughter's participation in sports would hinder their academic progress.

6. Women have more domestic day to day responsibilities before and after university hours and hence no time to participate in sports.

7. Parents do not permit their daughters to return home late in the evening after participation in sports.

8. Regarding personal vigilance many girls response was undecided. But, it was due to shyness only. It was assumed that parents fear that girls may lose vigilance if they were allowed to participate in sports.

9. Parents felt that their dignity will be degraded if the girls were allowed to participate in sports. 
10. Parents hesitate to encourage daughter's participation in sports because they consider it immodest for their daughters to wear sports uniform

11. Most of the female students (71\%) agreed for the statement regarding community always recognizes outstanding women for their achievement. This positive answer may be attributed to role modelling.

12. Friends and relatives do not encourage female to participate in sports.

13. Participation in sports and winning laurels and titles will help to get good name in the society. It was agreed by $86 \%$ of the respondents.

14. The attitude of men in the society is to discourage female participation in sports.

15. Nowadays, family customs are not restricting female participation in sports.

16. Social customs also in the present era are not restricting female participation in sports.

17. Participation in sports after the adolescence period causes problems.

18. Parents never allowed female to play along with men because it may have some ill affect on their marriage prospects.

19. Women studying in rural areas have more restrictions than those in urban areas.

20. Participation in sports may lead to understand changes in their character and there won't be any development and growth.

21. Participation in sports will develop indiscipline.

22. Women do not possess physical stamina required for sports activities.

23. Participation in sports is waste of time and energy. It will not help any more.

24. Women always prefer moving in group, engaging in subtle indoor activities.

25. Participation in sports makes them masculine and their feminity will be lost.

From the analysis of the responses to each statement in the questionnaire and with the help of percentages, it was found that majority of the respondents disagreed. The chi square value for all the statements was significant at 0.05 level of confidence and it inferred that the hypothesis, parental support may not influence female participation in sports was rejected. This means that parental support does influence female participation in sports.

\section{Discussion}

Through socialization one can develop observational learning, indirect coaching. Female university students have been poorly socialized by their parents towards sports during their formative years. A parent socializing their daughter to take part in sports at their formative years is related to parents' lack of interest in sports and their non-participation in sports. Due to combination of these factors they do not take their daughters out to watch sports competitions. They feel that the best recreation for girls should involve subtle indoor activities. Parents usually feel that sports will spoil their daughter's beauty and charm. In other words, through participation in sports they become masculine and is 
more likely put their femininity at risk because their participation in sports, challenges hegemonic notions of ideal femininity.

As the women are not exposed to varied objects in their life journey as men are, the sports activity goes less important in their scheme of life and this reflected in their level of sport activity considering the low level of attitude towards sports being dominant among them, a doubt arises whether their sports participation is prompted by internal motivation. Rather inducement and persuasion may be responsible for their entry into sports participation. This can be understood from the fact that in schools and colleges intramural tournaments and inter scholastic and inter collegiate tournaments, the women participation is not on their accord, but on the inducement exercised upon them by the authorities in-charge of the tournaments. In order that there is at least nominal representation of women in the contingents of sports persons for the tournaments, the authorities persuade and induce the women to participate in the tournaments. So, in the absence of the free will and involvement, the participation of female in sports goes mechanical and inspirited in such a condition, one cannot expect a high level of influence towards sports participation among them.

Sports activity is basically a masculine activity and it may in a way undermine their feminity and masculanise them. They have a fear in their minds that as participation in sports entails a heavy schedule of physical exercise, it may cause some adverse changes in their bodily structure, resulting in the loss of delicacy and other female qualities. The tendency of female as a reflection of the existing cultural myth that sports activity will undermine their feminine qualities. Above all, traditionally the roles of athlete and female are treated as opposite. Because sport is historically viewed as a male activity, females regarded it as one against their feminine image.

Sohi \& Yusuf (1990) had taken 180 subjects from India and 200 from Nigeria and conducted a study on family induced socialization into sports cross national observation. They found that parents of Nigerian students significantly participated as compared to those in India.

Sohi \& Singh (1990) selected 342 students of Ibadan University and conducted a study on socio-cultural deterrents to university female students' participation in sports and investigated that the subjects significantly greater number of them, of course considered the participation in sports as unfeminine behaviour. The socio-cultural beliefs, values and attitudes had been perceived by the female students as deterrents to their participation in sports. 
It is because of the factors that the female do not view the sport activity with zeal and fervor as men do. Lack of parental support and involvement, they are not in a position to appreciate the value of sports.

\section{Recommendations}

The investigators proposed here the following recommendations:

- Parental education regarding children participation in sports should be organized in schools and colleges.

- Teachers of physical education should provide up to date information regarding sports events. This can be done in the form of sending newsletter, parents' seminar, parent-teacher meetings and conferences.

- Physical education teachers should evolve parental involvement in sports activities.

- The existing system of education can be modified in such a way that physical education is given equal importance like any other subjects in the curriculum

- Female students should be duly motivated and properly encouraged to take part in sports.

- Female students who perform meritoriously in sports can be given preferences in admission in educational institutions and appointment and promotion in jobs.

- Required number of physical education teachers should appoint for girls.

- Involvement of various women organizations can contribute immensely for the development and for larger participation of women in sports.

- Provision of separate play grounds for women would go to a long way in encouraging female participation in sports.

- Community sports clubs and service centres exclusively for women can be set up in each locality.

\section{References}

Acosta, R. V. \& Carpenter, L. J. (1990). Women in Sport: A Longitudinal Study, New York: Brooklyn College.

Bourntiler, M. A. \& Giovanni, L. (1983). The sporting Women Illinois, Human Kinetics Publishers Inc.

Browne, J., Embrey, L., \& Rate, Y. (1987). Results of a Survey of Selected Secondary Schools Regarding Assessment in Physical Education Studies, Unpublished Doctoral Dissertation, Michigan State University, East Lansing. 
Dennison, B. A. (2002). A Socio-Psychological Assessment of Attitude Towards Physical Activity in Champion Athletes, Research Quarterly, vol. 41, pp. 1-9.

Huddleston, S., Mertesdorf, J. \& Araki, K. (2002). Physical Activity Behaviour and Attitudes Toward Involvement among Physical Education, Health and Leisure Services Professionals, College Students Journal, vol. 36, pp. 555-572.

Scarton, S. (1990). Gender and Physical Education, Geelong: Deakin University Press.

Selby, R. (1977). What's Wrong (and Right) with Coed Physical Education Classes: Secondary Physical Educator's Views on Title IX Implementation, Physical Educator, 34 (4), pp. 188-191.

Sohi, A. S. \& Yusuf, K. B. (1990). Some Observation of the Socio-Demographic Characteristics of Nigerian \& Indian Athletes, NIS Scientific Journal, vol. 12, No. 4, pp. 112-125.

Sohi, A. S. \& Singh, K. J. (1990). A Study of Socio Economic Background of Sports Women, Indian Journal of Sports Science \& Physical Education, vol. 6, No. 2, pp. 56-69.

Taylor, T. \& Toohey, K. (1998). Perspective Vision Sport Voices of Women from Non English Speaking Backgrounds, ACHPER Healthy Life Styles Journal, vol. 45, No.1, pp. 5-9.

Udoh, O. C. (1988). Recreation: An Indispensible Factor for Healthful Living in Contemporary Nigeria, In Ajala, J. A. (Ed), Recreation Education for Health and Natural Challenges, West Point, NV Leisure Press.

Dr. Shaista Naz is Assistant Professor in the Department of Education, Sindh Madressatul Islam University.

Dr. Hina Fazil is Assistant Professor in the Department of Special Education, University of the Punjab.

Prof. Dr. Nasir Sulman is Chairman in the Department of Special Education, University of Karachi. 